\title{
Pengaruh Electronic Word of Mouth, Tingkat Kepercayaan \\ Konsumen dan Minat Kunjungan Wisata Kuliner Kota Bogor
}

\author{
Terisia Ria Kristianti, Rezi Erdiansyah \\ rterisia@gmail.com,rezie@fikom.untar.ac.id
}

Fakultas Ilmu Komunikasi Universitas Tarumanagara

\begin{abstract}
This purposive of this research is to determine the effect of electronic word of mouth and consumer trust to visit intention of culinary tourism in Bogor City. This study took a sample of 105 respondents, by distributing questionnaires using the google form, where the requirements to become respondents were populations who had visited Bogor City. Data analysis using SEM, with statistical testing through the Lisrel 8.80 program. The results showed that electronic word of mouth had an influence on consumer trust and subsequently had implications for intention to visit Bogor culinary tourism. Thus, electronic word of mouth that is spread in various media should get the attention of tourism entrepreneurs, especially culinary tourism, if you want to increase tourist visits.
\end{abstract}

Keywords: consumer trust, culinary tourism bogor, electronic word of mouth, visit intention.

\begin{abstract}
Abstrak
Tujuan penelitian ini adalah untuk mengetahui apakah adanya pengaruh electronic word of mouth terhadap tingkat kepercayaan konsumen dan implikasinya pada minat kunjungan wisata kuliner Bogor. Peneliti menggunakan teori electronic word of mouth menurut Goyette et.al dengan tujuh indikator, teori tingkat kepercayaan konsumen menurut Delgado-Ballester et.al dengan empat indikator dan teori minat kunjungan menurut Middleton et.al dengan enam indikator. Penelitian ini mengambil sampel 105 responden, dengan penyebaran kuesioner yang dilakukan menggunakan google form, dimana syarat menjadi responden adalah populasi yang pernah melakukan kunjungan wisata kuliner Kota Bogor. Analisis data menggunakan SEM dengan pengujian statistik melalui program Lisrel 8.80. Hasil dari penelitian menunjukkan bahwa electronic word of mouth memiliki pengaruh terhadap tingkat kepercayaan konsumen dan selanjutnya berimplikasi terhadap minat kunjungan wisata kuliner Kota Bogor. Dengan demikian, electronic word of mouth yang tersebar pada berbagai media harus mendapat perhatian para pengusaha wisata, khususnya wisata kuliner, jika ingin meningkatkan kunjungan wisata.
\end{abstract}

Kata Kunci: Electronic Word of Mouth, minat kunjungan, tingkat kepercayaan konsumen, wisata kuliner bogor.

\section{Pendahuluan}

Minat merupakan suatu aktivitas psikis untuk mendorong seseorang dalam berperilaku tertentu dan mengambil suatu tindakan (Schiffman dan Kanuk, 2007; Maulidi dan Pangestuti, 2019). Dalam perspektif ekonomi, minat selalu dihubungkan dengan proses transaksional, khususnya keinginan untuk memutuskan pembelian terhadap suatu produk atau jasa. Oleh karena itu, pengertian minat beli sebagai suatu 
proses dalam kegiatan ekonomi sejalan dengan pengertian minat kunjungan wisata dalam kegiatan bisnis pariwisata (Kotler, 2000). Dengan demikian, bagi pelaku bisnis pariwisata maka perhatian terhadap berbagai faktor-faktor yang mempengaruhi minat kunjungan wisata harus mendapatkan perhatian sebagai faktor dominan dalam mengembangkan bisnis pariwisata.

Terdapat beberapa penelitian terkait minat kunjungan seperti Jalilvand et.al (2013) yang menyatakan bahwa minat kunjungan dipengaruhi oleh electronic word of mouth dan sikap terhadap tujuan (attitude toward destination). Sejalan dengan hasil tersebut, penelitian Al barq (2013) menemukan bahwa electronic word of mouth dan sikap wisatawan (attitude of tourist) berdampak positif terhadap niat melakukan perjalanan. Abu bakar dan Ilkan (2015) juga menemukan bahwa minat melakukan perjalanan dipengaruhi secara positif oleh online word of mouth dan destination trust. Selanjutnya Edithania (2018) menemukan bahwa nation branding terbukti signifikan berpengaruh positif terhadap minat berkunjung wisatawan.

Berdasarkan penelitian di atas, peneliti melihat terdapat peluang untuk meneliti lebih dalam mengenai minat kunjungan yang dipengaruhi oleh electronic word of mouth dan tingkat kepercayaan konsumen.

Electronic word of mouth didefinisikan sebagai pernyataan positif atau negatif dari mantan konsumen dan konsumen potensial mengenai sebuah produk/jasa yang dipaparkan secara terbuka melalui media internet (Jalilvand dan Samiei, 2012).

Sejalan dengan semakin ekspresifnya teknologi internet, electronic word of mouth telah dijadikan sebagai tempat bagi para konsumen untuk menyampaikan opini.

Beberapa data telah membuktikan bahwa online word of mouth begitu mempengaruhi konsumen. Forrester Research (2006) memperkirakan sebesar 34.7 persen konsumen melakukan pencarian online terkait wisata dan survei terbaru menemukan lebih dari 74 persen travelers menggunakan komentar konsumen lain sebagai sumber informasi ketika merencanakan perjalanan. Tripadvisor.com (2006) melaporkan bahwa konsumen secara online meninjau pendapat dan pengalaman dari konsumen lain terkait tujuan perjalanannya dan setiap tahun data menunjukkan adanya kenaikan yang signifikan.

Pada penelitian ini peneliti memilih wisata kuliner di Kota Bogor sebagai objek wisata yang diangkat. Kota Bogor adalah salah satu kota di Provinsi Jawa Barat, Indonesia yang memiliki daya tarik kunjungan wisatawan sebagai destinasi tujuan wisata masyarakat. Beberapa data menunjukkan terjadi kenaikan signifikan jumlah kunjungan wisatawan Bogor mulai tahun 2015 sampai tahun 2019. Data dari Rencana Strategis 2015-2019 Dinas Kebudayaan Pariwisata dan Ekonomi Kreatif Kota Bogor memaparkan jumlah kunjungan wisatawan nusantara mengalami kenaikan dari 3.769.787 hingga 6.071.128. Tak hanya itu jumlah kunjungan wisatawan mancanegara juga mengalami kenaikan dari 183.807 menjadi 296.023. Data ini membuktikan bahwa Kota Bogor adalah destinasi favorit terutama di bidang kuliner. 
Terisia Ria Kristianti, Rezi Erdiansyah: Pengaruh Electronic Word of Mouth, Tingkat Kepercayaan Konsumen dan Minat Kunjungan Wisata Kuliner Kota Bogor

\section{Electronic Word of Mouth}

Semuel dan Lianto (2014) menyatakan internet telah menciptakan sebuah paradigma baru dalam word of mouth dan awal munculnya sebuah istilah electronic word of mouth. Menurut Viviana dan Candraningrum (2018) electronic word of mouth merupakan informasi mouth to mouth yang dibagikan oleh sesama konsumen secara online sebagai bahan pertimbangan mengenai produk yang diteliti konsumen. Komunikasi electronic word of mouth dapat terjadi dalam berbagai pengaturan seperti konsumen dapat memposting pendapat, komentar dan ulasan di weblog, forum diskusi, situs web, sistem papan e-buletin, newsgroup, situs jejaring sosial untuk tukar-menukar informasi produk (Lee dan Han, 2008; Goldsmith, 2006).

Tucker berpendapat (dalam Al barq, 2014) bahwa terdapat beberapa penelitian yang menemukan bahwa electronic word of mouth lebih kuat daripada iklan. Didukung oleh pendapat Jalilvand dan Samiei (2012) bahwa electronic word of mouth sebagai tempat penting bagi konsumen memberikan opininya dan dianggap lebih efektif dibandingkan word of mouth karena tingkat aksesibilitas dan jangkauan electronic word of mouth lebih luas.

Menurut Goyette et. al (2010) terdapat tiga dimensi dalam electronic word of mouth yakni intensity, valence of opinion, dan content. Intensity meliputi frekuensi mengakses informasi, interaksi dengan pengguna dan jumlah ulasan yang ditulis oleh pengguna situs jejaring sosial. Valence of opinion meliputi komentar positif atau negatif serta rekomendasi dari pengguna situs jejaring sosial. Content meliputi ketersediaan informasi yang lengkap, kualitas dan harga yang ditawarkan.

\section{Tingkat Kepercayaan Konsumen}

Menurut Costabile (dalam Ferrinadewi, 2008) kepercayaan adalah persepsi konsumen terhadap kehandalan yang didasarkan oleh pengalaman transaksi dengan ciri harapan konsumen dapat terpenuhi atas kinerja produk dan kepuasan. Alesina dan Ferrara (2000) juga menambahkan pengalaman masa lalu menjadi dasar terbentuknya kepercayaan.

Kepercayaan dapat mengarah ke sikap positif konsumen terhadap suatu merek, meningkatkan loyalitas dan niat pembelian (Grazioli dan Jarvenpaa, 2000). Dengan demikian bila dikaitkan dengan minat kunjungan, kepercayaan memiliki pengaruh secara langsung maupun tidak langsung dan kemudian mengarah ke sikap positif terhadap suatu destinasi wisata serta menimbulkan niat untuk melakukan berkunjung. Artigas et. al (2017) menyatakan bahwa kepercayaan telah menjadi perhatian yang relevan untuk tujuan wisata. Menurut Delgado-Ballester et.al (2003) kepercayaan konsumen memiliki dua dimensi yaitu viability dan intentionality. Viability meliputi kepuasan dan nilai. Intentionality meliputi keamanan dan kepercayaan.

\section{Minat Kunjungan}

Minat berkunjung sebagai kecenderungan individu untuk melakukan kunjungan ke suatu destinasi dalam periode waktu tertentu di masa mendatang (Edithania, 2018). Kotler et. al (2006) mengatakan bahwa minat kunjungan wisatawan memiliki arti yang sama dengan minat beli konsumen, dalam praktiknya 
konsumen memiliki pertimbangan sebelum melakukan pembelian, perilaku tersebut juga muncul ketika seseorang akan mengunjungi suatu tempat wisata.

Menurut Middleton et.al (2009) terdapat tiga dimensi dari minat kunjungan yaitu problem recognition, information gathering dan evaluasi individu. Problem recognition meliputi dorongan kebutuhan dan meningkatkan kepuasan. Information gathering meliputi biaya, waktu dan infrastruktur, aksesibilitas dan pelayanan. Evaluasi individu meliputi niat dan keputusan untuk melakukan kunjungan.

\section{Hipotesis}

$\mathrm{H}_{1}$ : Electronic Word of Mouth berpengaruh positif dan signifikan terhadap Minat Kunjungan

$\mathrm{H}_{2}$ : Tingkat Kepercayaan Konsumen berpengaruh positif dan signifikan terhadap Minat Kunjungan

$\mathrm{H}_{3}$ : Electronic Word Of Mouth berpengaruh positif dan signifikan terhadap Tingkat Kepercayaan Konsumen

$\mathrm{H}_{4}$ : Electronic Word Of Mouth dan Tingkat Kepercayaan Konsumen secara simultan berpengaruh terhadap Minat Kunjungan

$\mathrm{H}_{5}$ : Electronic Word of Mouth berpengaruh terhadap Minat Kunjungan melalui Tingkat Kepercayaan Konsumen

\section{Metode Penelitian}

Penelitian ini dilakukan menggunakan survei kuantitatif. Penyebaran kuesioner dilakukan menggunakan google form. Terdapat tiga variabel dalam penelitian ini yaitu variabel electronic word of mouth dengan tujuh indikator, variabel tingkat kepercayaan konsumen dengan empat indikator dan variabel minat kunjungan dengan enam indikator. Uji validitas dan reliabilitas dalam penelitian ini menggunakan program SPSS 23. Uji hipotesis menggunakan program SEM Lisrel 8.80 .

\section{Hasil Temuan dan Diskusi}

Penelitian ini menerima 105 kuesioner valid. Dari hasil penyebaran kuesioner terdapat 32 responden pria (30.5\%) dan 73 responden perempuan $(69.5 \%)$. Sebaran usia, kurang dari 25 tahun sebanyak $77.1 \%$, usia antara 26 tahun hingga 30 tahun sebanyak $9.5 \%$, di atas 30 tahun sebanyak 13.4\%. Sebaran pekerjaan, 52 responden $(49.5 \%)$ adalah mahasiswa, $22(21 \%)$ adalah pegawai swasta dan $6(5.7 \%)$ adalah pegawai negeri sipil, selebihnya sebanyak 25 responden (23.8\%) menjawab lainnya. Berdasarkan asal kota, responden yang berasal dari Kota Jabodetabek sebanyak 57 orang (54.3) dan responden dari Luar Kota Jabodetabek sebanyak 48 orang $(45.7 \%)$. 
Terisia Ria Kristianti, Rezi Erdiansyah: Pengaruh Electronic Word of Mouth, Tingkat Kepercayaan Konsumen dan Minat Kunjungan Wisata Kuliner Kota Bogor

Tabel 1 Hasil Uji Validitas

\begin{tabular}{|c|c|c|c|}
\hline Variabel & Indikator & $\begin{array}{l}\text { Corrected } \\
\text { Item-Total } \\
\text { Correlation }\end{array}$ & Keterangan \\
\hline \multirow{7}{*}{$\begin{array}{l}\text { Electronic } \\
\text { Word of } \\
\text { Mouth }\end{array}$} & $\begin{array}{l}\text { Saya sering membaca review/ ulasan/ } \\
\text { komentar/ pendapat secara online mengenai } \\
\text { wisata kuliner Bogor. }\end{array}$ & 0.597 & Valid \\
\hline & $\begin{array}{l}\text { Saya menemukan banyak review/ ulasan/ } \\
\text { komentar/ pendapat dari konsumen lain secara } \\
\text { online mengenai wisata kuliner Bogor. }\end{array}$ & 0.568 & Valid \\
\hline & $\begin{array}{l}\text { Review/ ulasan/ komentar/ pendapat yang } \\
\text { positif, saya jadikan rujukan untuk } \\
\text { mengunjungi wisata kuliner Bogor. }\end{array}$ & 0.638 & Valid \\
\hline & $\begin{array}{l}\text { Saya juga memperoleh rekomendasi dari } \\
\text { konsumen lain mengenai tempat kuliner Bogor } \\
\text { yang layak dikunjungi. }\end{array}$ & 0.553 & Valid \\
\hline & $\begin{array}{l}\text { Saya mendapatkan informasi mengenai variasi } \\
\text { makanan dan minuman pada wisata kuliner } \\
\text { Bogor secara online. }\end{array}$ & 0.770 & Valid \\
\hline & $\begin{array}{l}\text { Saya mendapatkan informasi mengenai kualitas } \\
\text { wisata kuliner Bogor secara online. }\end{array}$ & 0.695 & Valid \\
\hline & $\begin{array}{l}\text { Saya mendapatkan informasi mengenai harga } \\
\text { yang ditawarkan pada wisata kuliner Bogor } \\
\text { secara online. }\end{array}$ & 0.594 & Valid \\
\hline \multirow{4}{*}{$\begin{array}{c}\text { Tingkat } \\
\text { Kepercayaan } \\
\text { Konsumen } \\
\text { (Consumer } \\
\text { Confidence/ } \\
\text { Consumer } \\
\text { Trust) }\end{array}$} & $\begin{array}{l}\text { Wisata kuliner Bogor dapat memenuhi harapan } \\
\text { saya. }\end{array}$ & 0.728 & Valid \\
\hline & $\begin{array}{l}\text { Wisata kuliner Bogor memberikan pelayanan } \\
\text { yang baik, ramah, dan menyenangkan. }\end{array}$ & 0.766 & Valid \\
\hline & $\begin{array}{l}\text { Saya merasa aman melakukan kunjungan } \\
\text { wisata kuliner di Bogor. }\end{array}$ & 0.662 & Valid \\
\hline & $\begin{array}{l}\text { Saya percaya apa yang tersedia pada wisata } \\
\text { kuliner Bogor menyenangkan. }\end{array}$ & 0.775 & Valid \\
\hline \multirow{3}{*}{$\begin{array}{l}\text { Minat } \\
\text { Kunjungan } \\
\text { (Visit } \\
\text { Intention) }\end{array}$} & $\begin{array}{l}\text { Saya melakukan kunjungan wisata kuliner } \\
\text { Bogor untuk memenuhi kebutuhan fisik, sosial } \\
\text { dan rohaniah. }\end{array}$ & 0.755 & Valid \\
\hline & $\begin{array}{l}\text { Saya melakukan kunjungan wisata kuliner } \\
\text { Bogor untuk memenuhi harapan/ keinginan dan } \\
\text { kepuasan saya di bidang kuliner. }\end{array}$ & 0.685 & Valid \\
\hline & $\begin{array}{l}\text { Saya melakukan kunjungan wisata kuliner } \\
\text { Bogor karena biaya dan waktu yang diperlukan } \\
\text { sesuai dengan kemampuan. }\end{array}$ & 0.703 & Valid \\
\hline
\end{tabular}




$\begin{array}{lll}\text { Saya melakukan kunjungan wisata kuliner } & 0.709 & \\ \text { Bogor juga dikarenakan ketersediaan } & & \text { Valid } \\ \text { infrastruktur, kemudahan akses dan pelayanan } & & \\ \text { yang baik. } & & \end{array}$

Saya berminat untuk selalu melakukan kunjungan wisata kuliner ke Bogor.

0.629

Valid

Saya memutuskan untuk berkunjung ke wisata kuliner Bogor setiap ada kesempatan yang tersedia.

Sumber: Data primer, diolah dengan SPSS 23.

Berdasarkan Tabel 1, 17 indikator dalam penelitian ini dapat dinyatakan valid karena nilai corrected item-total correlation setiap item lebih besar dari 0.5.

Tabel 2 Hasil Uji Reliabilitas

\begin{tabular}{lcc}
\hline \multicolumn{1}{c}{ Variabel } & Cronbach's Alpha & Keterangan \\
\hline $\begin{array}{l}\text { Electronic } \\
\text { Word of Mouth }\end{array}$ & 0.859 & Reliabel \\
\hline $\begin{array}{l}\text { Tingkat Kepercayaan } \\
\text { Konsumen }\end{array}$ & 0.876 & Reliabel \\
\hline Minat Kunjungan & 0.877 & Reliabel \\
& & \\
\hline
\end{tabular}

Sumber: Data primer, diolah dengan SPSS 23

Berdasarkan Tabel 2, tiga variabel dalam penelitian ini dapat dinyatakan reliabel dengan kategori baik karena nilai dari Cronbach's Alpha setiap variabel > 0.8 .

Tabel 3 Hasil Uji Hipotesis

\begin{tabular}{|c|c|c|c|c|}
\hline Hipotesis & Pengaruh & $\begin{array}{c}\text { Koefisien } \\
\text { Determinasi }\end{array}$ & T Value & Hasil \\
\hline $\mathrm{H}_{1}$ & Electronic Word of Mouth & 0.45 & 2.18 & Diterima \\
\hline $\mathrm{H}_{2}$ & Tingkat Kepercayaan Konsumen & 0.53 & 2.61 & Diterima \\
\hline $\mathrm{H}_{3}$ & $\begin{array}{c}\text { Electronic Word of Mouth } \\
\text { Tingkat Kepercayaan Konsumen }\end{array}$ & 0.85 & 5.81 & Diterima \\
\hline & $\begin{array}{c}\text { Electronic Word of Mouth } \\
\text { dan }\end{array}$ & & & Diterima \\
\hline
\end{tabular}


Terisia Ria Kristianti, Rezi Erdiansyah: Pengaruh Electronic Word of Mouth, Tingkat Kepercayaan Konsumen dan Minat Kunjungan Wisata Kuliner Kota Bogor

\begin{tabular}{ccccc}
\hline $\mathrm{H}_{4} \quad \begin{array}{c}\text { Tingkat Kepercayaan Konsumen } \\
\text { Minat Kunjungan }\end{array}$ & 0.43 & 2.02 & \\
\hline $\begin{array}{c}\text { Electronic Word of Mouth } \\
\text { melalui }\end{array}$ & & & \\
$\mathrm{H}_{5} \quad \begin{array}{c}\text { Tingkat Kepercayaan Konsumen } \\
\quad \begin{array}{c}\text { Minat Kunjungan } \\
\end{array}\end{array}$ & 0.53 & 2.60 & Diterima \\
\end{tabular}

Sumber: Data diolah dengan SEM Lisrel 8.80 .

\section{Diskusi}

Berdasarkan tabel 3 dapat dilihat semua hipotesis terbukti positif dan signifikan. Electronic word of mouth dan tingkat kepercayaan konsumen berpengaruh terhadap minat kunjungan. Tingkat kepercayaan konsumen memiliki pengaruh yang lebih besar dari pada electronic word of mouth. Namun demikian, tingkat kepercayaan merupakan mediasi dari pengaruh electronic word of mouth terhadap minat kunjungan. Hal ini menunjukkan bahwa meningkatkan kepercayaan konsumen perlu memperhatikan electronic word of mouth. Hasil dari hipotesis penelitian ini sama dengan hasil penelitian Abubakar (2015) dan Abubakar et.al (2017) yang menemukan bahwa kepercayaan wisatawan secara positif mempengaruhi niat melakukan perjalanan. Beberapa penelitian lain seperti Jalilvand et.al (2013), Albarq (2013), Abubakar (2015) menyatakan bahwa electronic word of mouth memiliki dampak positif dan signifikan terhadap niat untuk kunjungan. Lassoued dan Hobbs (2014) menyebutkan peran mediasi dan efek besar dari kepercayaan bahwa menanamkan hubungan kepercayaan dengan konsumen merupakan elemen kunci dalam meningkatkan kepercayaan publik yang akhirnya menjadi kepercayaan konsumen. Pendapat yang sama dikemukakan oleh Micallef dan Pappas (2017) yang mengatakan kepercayaan sebagai mediasi yang dapat menjaga hubungan positif yang kuat.

\section{Simpulan}

Berdasarkan hasil koefisien determinasi dan $T$ values, peneliti menarik kesimpulan bahwa peningkatan minat kunjungan begitu dipengaruhi oleh kepercayaan konsumen. Hal ini menunjukkan bahwa untuk meningkatkan kepercayaan konsumen, perlu menciptakan rasa aman dan senang dari konsumen terkait wisata kuliner Bogor. Namun, kepercayaan konsumen juga dibangun oleh electronic word of mouth yang positif. Karena konsumen sering kali melakukan tinjauan informasi secara online terkait wisata kuliner Bogor untuk dijadikan sebagai rujukan. Dengan demikian, banyaknya electronic word of mouth yang positif mengenai wisata kuliner Bogor tentu menciptakan tingkat kepercayaan konsumen serta meningkatkan minat untuk melakukan kunjungan wisata kuliner Bogor. 


\section{Ucapan Terima Kasih}

Peneliti mengucapkan terima kasih kepada keluarga dan seluruh pihak yang telah berkontribusi serta mendukung penelitian ini terselesaikan dengan tepat waktu.

\section{Daftar Pustaka}

Abubabakar, A. Mohammed., Ilkan, Mustafa., Al-Tal, Raad Meshall., \& Eluwole, Kayode Kolawole. (2017). EWOM, revisit intention, destination trust and gender. Journal of Hospitality and Tourism Management, 31, 220-227.

Abubakar, Mohammed., \& Ilkan, Mustafa. (2015). Impact Online WOM on Destination Trust and Intention to Travel: A Medical Tourism Perspective. Journal of Destination Marketing and Management, 5, 192-201.

Albarq, Abbas N. (2014). Measuring the Impacts of Online Word-of-Mouth on Tourists' Attitude and Intentions to Visit Jordan: An Empirical Study. International Business Research, 7, 14-22.

Alesina, Alberto., \& Ferrara, Eliana La. (2000). The Determinants of Trust. National Bureau of Economic Research, 7621, 1-34.

Artigas, Enrique Marino., Yrigoyen, Croco Chasco., Moraga, Eduardo Torres., \& Villalon, Cristobal Barra. (2017). Determinants of trust towards tourist destinations. Journal of Destination Marketing and Management, 6, 327-334.

Data Terbuka Kota Bogor. (2017). Rencana Strategis 2015-2019: Dinas Kebudayaan Pariwisata dan Ekonomi Kreatif Kota Bogor. Oktober 11, 2019. http://data.kotabogor.go.id/dataset/rencana-strategis-2015-2019-dinaskebudayaan-pariwisata-dan-ekonomi-kreatif-kota-bogor/resource/499e 19440a2d-43b2-b4b0-e9f493bf01ef

Delgado-Ballester, E. (2003). Development and Validation of A Brand Trust Scale. International Journal of Market Research, 45, 171-185.

Edithania, Regina Oktaria. (2018). Pengaruh Nation Branding "Pesona Indonesia" Terhadap Minat Berkunjung Wisatawan Nusantara (Survei Pada Pengikut Instagram @pesonaid_travel). Jurnal Manajemen Bisnis, 13, 1-23.

Ferrinadewi, Erna. (2008). Merek dan Psikologi Konsumen. Yogyakarta: Graha Ilmu.

Forrester Research. (2006). The State of Retailing Online 2006: The $9^{\text {th }}$ Annual Shop.org Study. Oktober 13, 2019. http://www.clickz.com/3611181

Goldsmith, R. E. (Ed.) (2006) Encyclopedia of E-Commerce, E-Government and Mobile Commerce. Idea Group Publishing.

Goyette, I., Ricard, L., Bergeron, J., \& Marticotte, F. (2010). e-WOM Scale: Wordof-Mouth Measurement Scale for e-Services Context. Canadian Journal of Administrative Sciences, 27, 5-23.

Grazioli, S., \& Jarvenpaa, S. L. (2000). Perils of internet fraud: An empirical investigation of deception and trust with experienced internet consumers. IEEE Transactions on Systems, Man, and Cybernetics - Part A: Systems and Humans, 30, 395-410. 
Terisia Ria Kristianti, Rezi Erdiansyah: Pengaruh Electronic Word of Mouth, Tingkat Kepercayaan Konsumen dan Minat Kunjungan Wisata Kuliner Kota Bogor

Herlina, Vivi. (2019). Panduan Praktik Mengolah Data Kuesioner Menggunakan SPSS. Jakarta: PT Elex Media Komputindo.

Jalilvand, M.R., Ebrahimi, Abolghasem., \& Samiei, Neda. (2013). Electronic Word of Mouth Effect on Tourist's Attitudes Toward Islamic Destinations and Travel Intention: an Empirical Study in Iran. Procedia - Social and Behavioral Sciences, 81, 484-489.

Jalilvand, M.R., \& Samiei, Neda. (2012). The effect of electronic word of mouth on brand image and purchase intention: An empirical study in the automobile industry in Iran. Marketing Intelligence and Planning, 30, 460-476.

Kotler, Philip., Bowen, John T., \& Makens, James C. (2006). Marketing Hospitality and Tourism. New Jersey: Pearson Education.

Lassoued, R., Hobbs, J.E. (2015). Consumer confidence in credence attributes: The role of brand trust. Food Policy, 5, 99-107.

Lee, J., Park, D.-H. \& Han, I. (2008). The effect of negative online consumer reviews on product attitude: An information processing view. Electronic Commerce Research and Applications, 7, 341.

Maulidi, Wildan Syahrul., \& Pangestuti, Edriana. (2019). Pengaruh Electronic Word of Mouth (EWOM) Di Instagram Terhadap Minat Berkunjung dan Dampaknya Terhadap Keputusan Berkunjung. Jurnal Administrasi Bisnis, $71,40-50$.

Middleton, V.T.C, Fyall, A., Morgan, M., \& Ranchhod, A. (2009). Marketing in travel and tourism (4th ed.). Great Britain: Elsevier.

Mikalef, Patrick., \& Pappas, Ilias O. (Agustus, 2017). Value Co-Creation and Purchase Intention In Social Commerce: The Enabling Role of Word of Mouth and Trust. Makalah dipresentasikan dalam Twenty-third Americas Conference on Information Systems, Boston.

Schiffman, Leon., \& L, Leslie. (2007). Perilaku Konsumen. Jakarta: PT Indeks.

Semuel, Hatane.., \& Lianto, Adi Suryanata. (2014). Analisis eWOM, Brand Image, Brand Trust dan Minat Beli Produk Smartphone di Surabaya. Jurnal Manajemen Pemasaran, 8, 47-54.

Sugiyono. (2016). Metode Penelitian Kuantitatif, Kualitatif dan R\&D. Bandung: Alfabeta.

Tripadvisor.com. (2011). Oktober 13, 2019. @/http://tripadvisor.com

Viviana, Chintya., \& Candraningrum, Diah Ayu. (2018). E-Wom Oleh Kalangan Milenial Terhadap Akun @makansampaikenyang Sebagai Pemberi Rekomendasi Kuliner. Jurnal Komunikasi, 2, 270-277. 